\title{
Revisão por pares: um estudo da gestão de avaliadores nas revistas científicas brasileiras
}

Discente: Elisabete Werlang

Orientadora: Dra. Ursula Blattmann - PGCIN/UFSC

Coorientador: Dr. Vinícius Medina Kern - PGCIN/UFSC

Banca: Dra. Nadi Helena Presser - PPGCI/UFPE

Dr. Márcio Matias - CIN/UFSC

Dra. Gleisy Regina Bóries Fachin - CIN/UFSC

\section{RESUMO}

Os periódicos científicos são o principal meio formal de registro e disseminação das pesquisas científicas e a etapa mais polêmica do fluxo editorial é a revisão por pares. Esta pesquisa teve como objetivo descrever o processo da gestão de avaliadores na consolidação das revistas científicas brasileiras, bem como identificar características dos editores e das revistas, identificar os processos de avaliação adotados e suas características, levantar as vantagens e desvantagens desse modelo de avaliação, identificar características do perfil dos avaliadores e levantar os critérios utilizados pelos editores na escolha, permanência e desligamento de avaliadores. Segundo sua finalidade, trata-se de uma pesquisa aplicada e a linha geral que norteou o presente estudo foi a pesquisa exploratória e descritiva, por meio de emprego de métodos quantitativos de análise, tendo como delineamento a pesquisa bibliográfica e o levantamento, utilizando como instrumento de coleta de dados, o questionário. 0 objeto de análise estendeu sua ação em 103 respondentes, dos 477 editores de revistas científicas associados à Associação Brasileira de Editores Científicos (ABEC). A pesquisa apontou que o modelo de avaliação mais utilizado é o double blind peer review, que se efetiva por meio do parecer de 2 especialistas que avaliam, em média, até 3 artigos ao ano, recebendo, a priori, orientações dos editores sobre as avaliações a serem realizadas. A principal vantagem apontada desse modelo de avaliação é a qualidade da publicação, porém, apresenta desvantagem em relação à demora que impõe ao fluxo editorial. Os avaliadores são selecionados com base em critérios, tais como, titulação em nível de doutorado na área, experiência como pesquisador e por terem realizado a avaliação com justiça, equilíbrio e clareza. Os novos avaliadores são selecionados pelo Currículo Lattes e as revistas possuem até 500 avaliadores cadastrados, entretanto, a maioria já descadastrou avaliadores por descumprimento de prazos e por não informar em sobre sua disponibilidade para avaliação quando solicitados. Os avaliadores não são remunerados financeiramente, mas recebem certificados de reconhecimento. Os 
editores, em sua maioria, têm até cinco anos de experiência e a maioria das revistas é editada no formato impresso e on-line, simultaneamente. Este estudo sistematizou informações sobre a gestão de avaliadores de revistas científicas e evidenciou o papel fundamental do Currículo Lattes, como fonte de informação para a seleção de avaliadores, o cumprimento de prazos e a emissão de pareceres justos como aspectos relevantes para a permanência na função de avaliador.

Palavras-chave: Revisão por pares. Avaliação pelos pares. Revistas Científicas. Fluxo Editorial. 